\title{
Hepatic Steatosis in Patients with Metabolic Syndrome at the Brazzaville University Hospital Center
}

\author{
Clausina Ahoui-Apendi1,2, Ngala Akoa Itoua-Ngaporo1,2, Arnaud Mongo-Onkouo1,2, \\ Moubié Malanda Merveille ${ }^{2}$, Jile Florient Mimiesse ${ }^{1,2}$, Nestor Andzouana Bahamognoua2,3, \\ Régis Moyikoua ${ }^{2,4}$, Rody Stéphane Ngami1,2, Ngalessami Mouakosso Marlyse ${ }^{1}$, Deby Gassaye ${ }^{1,2}$, \\ Blaise Irénée Atipo Ibara1,2, Ibara Jean-Rosaire ${ }^{1,2}$
}

\footnotetext{
${ }^{1}$ Department of Gastroenterology and Internal Medicine, CHU Brazzaville, Brazzaville, Congo

${ }^{2}$ Faculty of Health Sciences, Marien Ngouabi University of Brazzaville, Brazzaville, Congo

${ }^{3}$ Department of Metabolic and Endocrine Diseases, CHU Brazzaville, Brazzaville, Congo

${ }^{4}$ Radiology Department, Brazzaville University Hospital, Brazzaville, Congo

Email: madamemikolele@gmail.com
}

How to cite this paper: Ahoui-Apendi, C., Itoua-Ngaporo, N.A., Mongo-Onkouo, A., Merveille, M.M., Mimiesse, J.F., Bahamognoua, N.A., Moyikoua, R., Ngami, R.S., Marlyse, N.M., Gassaye, D., Ibara, B.I.A. and Jean-Rosaire, I. (2020) Hepatic Steatosis in Patients with Metabolic Syndrome at the Brazzaville University Hospital Center. Open Journal of Gastroenterology, 10, 119-127. https://doi.org/10.4236/ojgas.2020.106012

Received: April 12, 2020

Accepted: May 25, 2020

Published: May 28, 2020

Copyright $\odot 2020$ by author(s) and Scientific Research Publishing Inc. This work is licensed under the Creative Commons Attribution International License (CC BY 4.0).

http://creativecommons.org/licenses/by/4.0/

\section{(c) (i) Open Access}

\begin{abstract}
Objective: To study the epidemiological, clinical and paraclinical particularities of fatty liver disease in patients with metabolic syndrome. Patients and Method: This was a cross-sectional and analytical study carried out over a period of seven months, from February 1 to September 30, 2019, in the outpatient services of Gastroenterology and Metabolic and Endocrine Diseases of the Brazzaville University Hospital. It interested all patients with metabolic syndrome, according to the criteria of the FID harmonized in 2009, namely known diabetic and hypertensive patients, having abdominal obesity. Results: The variables studied were socio-demographic, clinical, morphological and biological. The search for fatty liver was done using an abdominal ultrasound. Results: During the study period, 124 patients with metabolic syndrome were included. The average age of the population was $52.8 \pm 12$ years with extremes ranging from 30 and 84 years. The population was mainly female with a Sex-Ratio of $2.54(\mathrm{~F} / \mathrm{M})$. The frequency of fatty liver disease was $38.7 \%$. The frequency of dyslipidemia was high in the study. Conclusion: The prevalence of hepatic steatosis is high in patients with metabolic syndrome at Brazzaville University Hospital. The gender, lack of occupation and high level of education were the factors associated with fatty liver disease.
\end{abstract}

\section{Keywords}

Fatty Liver, Metabolic Syndrome, Brazzaville 


\section{Introduction}

The prevalence of Non alcoholic fatty liver disease (NAFLD) is increasing worldwide, currently constituting one of the main causes of cirrhosis and hepatocellular carcinoma. In fact, in 2018, it was estimated at $25.2 \%$ in the world population and reached 30\% in the West [1] [2] [3]. This increase, which has been constant for several years, appears to be correlated with the global epidemic of obesity and diabetes [4]. Fibroscan ${ }^{\oplus}$, MRI and histological analysis of liver biopsies are reliable quantitative tests, but abdominal ultrasound remains the most accessible screening test in Africa [5]. In Burundi, a recent study reported a high frequency of fatty liver diagnosed on abdominal ultrasound, in patients with metabolic syndrome [6]. In the Congo, no work has addressed this comorbidity. This is how we undertook this work, the objective of which was to determine the frequency of steatosis in patients with metabolic syndrome and then to identify the associated epidemiological, clinical, morphological and biological characteristics.

\section{Patients and Methods}

This was a cross-sectional and analytical study carried out over a period of seven months, from February 1 to September 30, 2019 in the outpatient services of Gastroenterology and Metabolic and Endocrine Diseases of the Brazzaville University Hospital. It interested all the patients seen in ambulatory consultation, presenting a clinical metabolic syndrome, defined according to the criteria of the FID harmonized in 2009 [7]. Due to a bias related to pathological or physiological weight gain, patients on long-term corticosteroid therapy, patients with ascites or ananasarcosis and pregnant women were not included. The study data were collected on a pre-established survey form after obtaining the patient's informed consent. The study data were collected on a pre-established survey form after obtaining the patient's informed consent. The practice of regular physical activity of at least thirty minutes a day, at least 3 days a week made us rule out sedentary lifestyle. Microsoft Office Excel 2016 software was used for the preparation and processing of the database. The software $\mathrm{R}$ version 3.6.1 allowed statistical analysis (Student and Chi-square test, Odds ratio and CI) with a significance threshold fixed at $5 \%$.

\section{Results}

\section{General Patient Characteristics}

\section{1) Socio-Demographic Factors of Patients}

During the study period, 124 patients with a metabolic syndrome combining hypertension, type 2 diabetes and abdominal obesity were collected. There were 89 (72\%) women and $35(28 \%)$ men, a sex ratio of 0.3 . The mean age of the patients was $52.8 \pm 12$ years with extremes of 30 and 84 years. The most represented age group was that of 40 to 65 years old. Figure 1 illustrates the distribution of patients by sex and age. In our sample, 92 patients had a secondary education level or $74.2 \%$ and 92 patients were unemployed or $74 \%$. Physical inactivity was found in $117 \mathrm{pa}$ tients (94.4\%). Only three patients (2.4\%) used tobacco and 15 (12.1\%) used alcohol. 


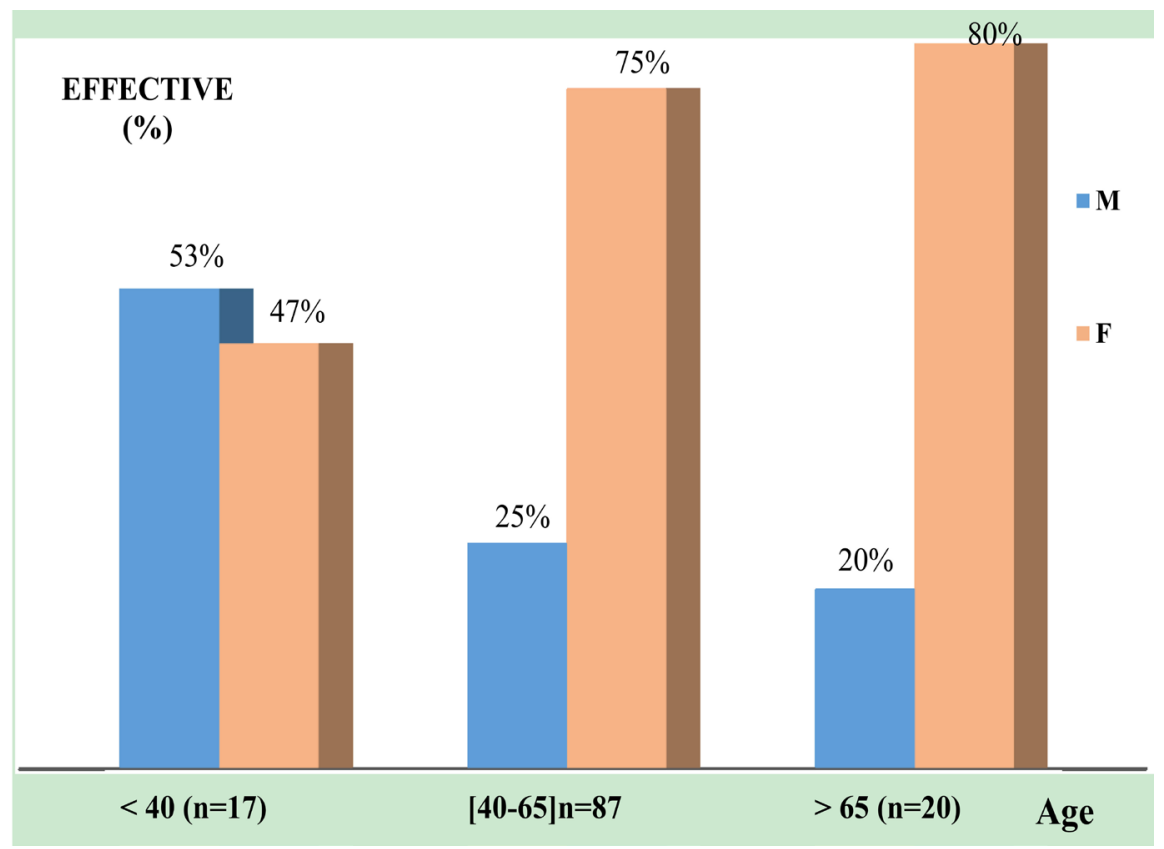

Figure 1. Distribution of patients by sex and age.

\section{2) Patient Clinical Data}

The waist circumference varied between $80 \mathrm{~cm}$ and $197 \mathrm{~cm}$ i.e. an average of $104.68 \pm 13 \mathrm{~cm}$ (median: $104 \mathrm{~cm}$ ). The average body mass index (BMI) was 31.07 $\pm 4.7 \mathrm{~kg} / \mathrm{m}^{2}$ (median: $31 \mathrm{~kg} / \mathrm{m}^{2}$; range: $17.99-46.36 \mathrm{~kg} / \mathrm{m}^{2}$ ). Seventy-six patients $(61.3 \%$ or $61.3 \%, \mathrm{n}=76)$ were obese with a female predominance in $71.1 \%$ of the cases $(\mathrm{n}=54 / 76)$.

\section{3) Patient Ultrasound Data}

Regarding dyslipidemia, 33 patients or $26.6 \%$ had hypercholesterolemia (mean: $1.72 \pm 0.35 \mathrm{~g} / \mathrm{l}$; extremes: $0.48-3.03 \mathrm{~g} / \mathrm{l}$ ), 20 patients or $16.1 \%$ hypertriglyceridemia (mean: $1.28 \pm 0.46 \mathrm{~g} / \mathrm{l}$; range: $0.45-3.86 \mathrm{~g} / \mathrm{l}$ ), 17 patients with low HDL (mean: $0.54 \mathrm{~g} / \mathrm{l} \pm 0.20 \mathrm{~g} / \mathrm{l}$; range: $0,15-1.77 \mathrm{~g} / \mathrm{l}$ ).) The LDL cholesterol value was normal in all patients (mean: $1.03 \pm 0.33 \mathrm{~g} / \mathrm{l}$; extremes: $0.01-1.57 \mathrm{~g} / \mathrm{l}$ ). The average age of patients with fatty liver disease was 51.8 years (range 34 and 77 years) versus 53.4 years in patients without fatty liver. Hepatic steatosis was statistically significantly associated with male sex $(p=0.001)$. Table 1 shows the distribution of steatosis according to the epidemiological parameters of the patients.

The mean value of blood pressure was slightly higher in patients with fatty liver disease. Indeed, the mean PAS was $148.93 \mathrm{mmHg}$ (range: 110 - $190 \mathrm{mmHg}$ ) in patients with fatty liver and $145.61 \mathrm{mmHg}$ (range: $100-210 \mathrm{mmHg}$ ) in patients without fatty liver. That of the PAD was $85.35 \mathrm{mmHg}$ (range: $60-160$ $\mathrm{mmHg}$ ) versus $82.86 \mathrm{mmHg}(60-107 \mathrm{mmHg})$. The difference was not significant.

The average waist size in patients with fatty liver was $105.7 \mathrm{~cm}$ (range: $81-137$ $\mathrm{cm}$ ) and $104.1 \mathrm{~cm}$ (range: $80-197 \mathrm{~cm}$ ) in those without fatty tissue with a sig- 
nificant difference $(\mathrm{p}=0.001)$. The average weight was $92.57 \mathrm{~kg}$ (range: 67.4 $144 \mathrm{~kg}$ ) versus $83.21 \mathrm{~kg} / \mathrm{m}^{2}$ (range: $49-131 \mathrm{~kg}$ ) in patients without fatty liver disease $(\mathrm{p}=0.541)$.

The average BMI was $32.40 \mathrm{~kg} / \mathrm{m}^{2}$ (range: $22.78-46.36 \mathrm{~kg} / \mathrm{m}^{2}$ ) versus 30.23 $\mathrm{kg} / \mathrm{m}^{2}$ (range: $\left.17.99-43.26 \mathrm{~kg} / \mathrm{m}^{2}\right)$ without fatty liver $(\mathrm{p}=0.82)$. The average BMI was $32.40 \mathrm{~kg} / \mathrm{m}^{2}$ (range: $22.78-46.36 \mathrm{~kg} / \mathrm{m}^{2}$ ) versus $30.23 \mathrm{~kg} / \mathrm{m}^{2}$ (range: $\left.17.99-43.26 \mathrm{~kg} / \mathrm{m}^{2}\right)$ without fatty liver $(\mathrm{p}=0.82)$. Figure 2 shows the changes in BMI within the two groups.

The mean blood sugar level in patients with fatty liver was $1.51 \mathrm{~g} / \mathrm{l}$ (range: 0.77 - $3.86 \mathrm{~g} / \mathrm{l}$ ) and $1.46 \mathrm{~g} / \mathrm{l}$ in patients without fatty liver with no statistically significant difference. The mean lipid value was equal in the two populations. It was $1.3 \mathrm{~g} / \mathrm{l}$ (range: 0.45 - $3.86 \mathrm{~g} / \mathrm{l}$ ) for TG, $1.7 \mathrm{~g} / \mathrm{l}$ (range: $1.06-2.45 \mathrm{~g} / \mathrm{l}$ ) for CT, $0.5 \mathrm{~g} / \mathrm{l}$ (range: $0.15-1.38 \mathrm{~g} / \mathrm{l}$ ) for HDL and $1 \mathrm{~g} / \mathrm{l}$ (range: $0.5-1.52 \mathrm{~g} / \mathrm{l}$ ) for LDL cholesterol.

After multivariate logistic regression analysis, the variables that best predicted fatty liver disease were male, lack of occupation and high level of education. Table 2 shows the results of the multivariate analysis.

Table 1. Distribution of steatosis according to the epidemiological parameters of the patients.

\begin{tabular}{|c|c|c|c|c|c|c|}
\hline \multirow{2}{*}{ Variables } & \multirow[b]{2}{*}{ Terms } & \multicolumn{2}{|c|}{$\begin{array}{l}\text { Steatosis present } \\
\qquad(\mathrm{n}=48)\end{array}$} & \multicolumn{2}{|c|}{$\begin{array}{l}\text { Stéatose absent } \\
\qquad(\mathrm{n}=76)\end{array}$} & \multirow{2}{*}{$\begin{array}{c}\mathrm{p} \text { value } \\
(\mathrm{p}<0.005)\end{array}$} \\
\hline & & $\mathrm{n}$ & $\%$ & $\mathbf{n}$ & $\%$ & \\
\hline \multirow{3}{*}{ Age (years) } & $<40$ & 7 & 14.6 & 10 & 13.2 & \multirow{3}{*}{0.921} \\
\hline & {$[40-65]$} & 34 & 70.8 & 53 & 69.7 & \\
\hline & $>65$ & 7 & 14.6 & 13 & 17.1 & \\
\hline \multirow[b]{2}{*}{ Sex } & Male & 24 & 50 & 11 & 14.5 & \multirow[b]{2}{*}{$<0.001$} \\
\hline & Feminine & 24 & 50 & 65 & 85.5 & \\
\hline \multirow{3}{*}{ Profession } & Yes & 29 & 60.5 & 23 & 30.3 & \multirow{3}{*}{0.001} \\
\hline & & & & & & \\
\hline & No & 19 & 39.5 & 53 & 69.7 & \\
\hline \multirow{3}{*}{ Tobacco } & Yes & 2 & 4.2 & 1 & 1.3 & \multirow{3}{*}{0.559} \\
\hline & & & & & & \\
\hline & No & 46 & 95.8 & 75 & 98.7 & \\
\hline \multirow{3}{*}{ Alcohol } & Yes & 9 & 18.7 & 6 & 7.8 & \multirow{3}{*}{0.128} \\
\hline & & & & & & \\
\hline & No & 39 & 81.3 & 70 & 92.2 & \\
\hline \multirow{3}{*}{ Type of diabetes } & I & - & - & 1 & 1.32 & \multirow{3}{*}{1} \\
\hline & & & & & & \\
\hline & II & 48 & 100 & 75 & 98.7 & \\
\hline \multirow{3}{*}{ Physical activity } & Oui & 3 & 6.2 & 4 & 5.3 & \multirow{3}{*}{1} \\
\hline & & & & & & \\
\hline & Non & 45 & 93.8 & 72 & 94.7 & \\
\hline
\end{tabular}


Table 2. Results of the multivariate analysis of fatty liver disease.

\begin{tabular}{cccccc}
\hline Variables & Terms & $\begin{array}{c}\text { Steatosis } \\
\text { Present } \\
\mathbf{n}=\mathbf{4 8}(\%)\end{array}$ & $\begin{array}{c}\text { Steatosis } \\
\text { Absent } \\
\mathbf{n}=\mathbf{7 6}(\%)\end{array}$ & OR [IR 95] & $\begin{array}{c}\mathrm{p} \text { value } \\
(\mathrm{p}<0.005)\end{array}$ \\
\hline Sex & $\mathrm{M}$ & $24(50)$ & $66(85.5)$ & Ref & Ref \\
\hline \multirow{2}{*}{ Profession } & F & $24(50)$ & $11(14.5)$ & $5.91[2.52-13.9]$ & $\mathbf{0 . 0 0 1}$ \\
\hline \multirow{2}{*}{$\begin{array}{c}\text { Education } \\
\text { level }\end{array}$} & No & $29(60.5)$ & $23(30.3)$ & Ref, & Ref, \\
& Primary & $8(16.7)$ & $13(17.1)$ & $1.21[0.45-3.23]$ & 0.7 \\
& secondary & $31(64.5)$ & $61(80.3)$ & Ref & Ref \\
& University & $1(2.1)$ & $2(2.6)$ & $0.98[0.98-11.3]$ & $\mathbf{0 . 0 0 1}$ \\
\hline
\end{tabular}

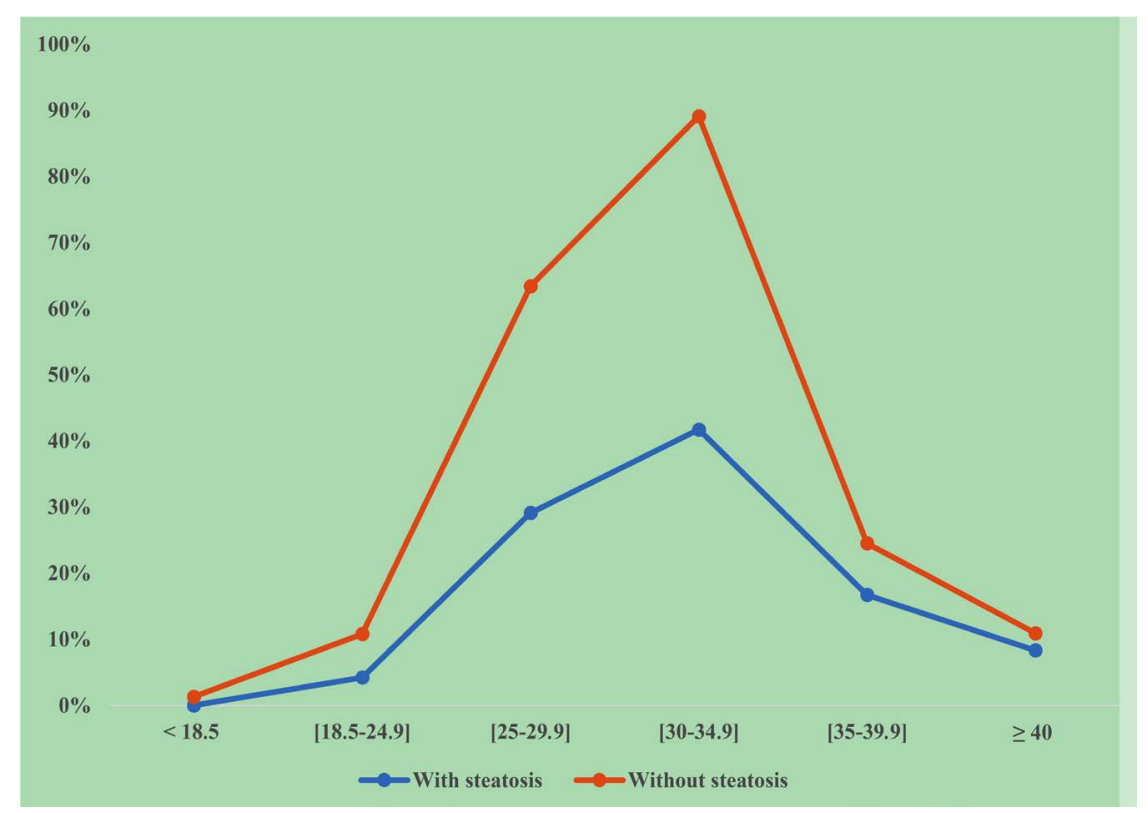

Figure 2. Distribution of patients in the two groups according to BMI.

\section{Discussion}

In the Congo, as little work has been published on fatty liver disease, we have chosen to look for it in patients with metabolic syndrome because they constitute a population potentially at risk. Metabolic syndrome is a pathology of the elderly, the average age at the time of diagnosis being generally close to fifty [8]. Ce phénomène est probablement favorisé par la sédentarité dans cette tranche d'âge qui de plus est exposée aux complications liées au diabète et à l'obésité [9]. Yaméogo et al. in Burkina Faso also made the same observation in their study (average age of $53.5 \pm 13.5$ years) [10]. The predominance of women during metabolic syndrome is frequently found, as shown by the work of Monabeka et al. in Congo in 2012 and Mbaye et al. in Senegal in 2018 [11] [12]. The role of physi- 
cal inactivity in the onset of metabolic syndrome is well known, as are alcohol and tobacco. The combination of these three factors contributes to the worsening of the metabolic syndrome and the pathogenesis of fatty liver disease. The high frequency of obesity in female subjects could be explained, on the one hand, by certain events in the life of women such as childbirth and menopause [13]; on the other hand, by the culture and the westernized way of life in the Congolese population in general. Indeed, we are witnessing in developing countries like ours, the transition from a low-fat diet and a physically active life to a diet richer in saturated animal fats and a sedentary lifestyle. Other studies corroborate this observation [14] [15]. The frequency of steatosis found in our work is similar to that reported by Ntagirabiri et al. in 2014 in Burundi (37.2\%) [6]. In contrast, Asabamaka et al. in 2011 in Nigeria reported a frequency (9\%) lower than ours [16]. All these frequencies are lower than those of Western countries where they vary between 50\% and 90\% [4] [17] [18]. This difference could be explained on the one hand by the diagnostic methods used in Europe (liver biopsy and/or impulse elastometry), on the other hand, by the different way of life although in recent years the way of life in Africa's Westernizes more and more. A third factor that could explain this low incidence of steatosis in our population is the black race. Indeed, some studies have shown that black subjects were generally less affected by steatosis than white subjects [19] [20]. However, abdominal ultrasound remains the most accessible screening test, although its performance varies depending on the study and the degree of steatosis. Indeed, steatosis can also be objectified by the abdominal scanner, but better by impulse elastometry where it can be quantified or by histological examination after liver biopsy. But these means of exploration are not in common use in our country because of their high cost and the fact that they are not very popular in the various health centers without forgetting the invasive nature of the liver biopsy. In a mixed analysis, hepatomegaly was associated with the presence of fatty liver disease. Indeed, the presence of hepatomegaly is possible in some cases and could be explained by the reaction of the liver to the hepatic overload of triglycerides [21]. The average age of patients with fatty liver disease is similar to the data in the literature. The risk of developing NAFLD increases with age, although it can occur in children under the age of 10 years [22]. The distribution of steatosis by sex is variable depending on the study. Ntagirabiri et al. in Burundi as well as Somaya et al. in Morocco noted a female predominance in $41.8 \%$ of the cases and in $50.4 \%$ of the cases respectively [6] [23]. In our series, this result could be explained by the frequency of certain risk factors such as alcohol, tobacco, hypertension and abdominal obesity which were more important in men. In the study by Ntagirabiri et al., the number of patients without steatosis decreased inversely with the high BMI values, with a significant difference [6]. These results, opposite to ours, could be explained by the difference in methodology since their population was heterogeneous (patients with and without metabolic syndrome) whereas in our study all the patients had diabetes integrated into a metabolic syndrome. As for relation to the absence of profession, 
this state could favor the sedentary lifestyle and thus the metabolic syndrome and the fatty liver. Likewise, the high level of education could favor obesity and the metabolic syndrome by the fact that it favors the adoption of a westernized lifestyle including bad eating habits. Dyslipidemia is common in the diabetic population and is a major risk factor for the occurrence of cardiovascular events. Indeed, hypertriglyceridemia, hypercholesterolemia, the low value of HDL in some of our patients are the elements most found in studies carried out in Burundi, Nigeria, Kenya and South Africa [6] [16] [24] [25]. Certain factors such as genetic predisposition, physical inactivity and eating habits may explain these results. Hypertriglyceridemia is one of the lipid disorders described as being linked to steatosis. However, in our study, as in those of Ntagirabiri et al. in Burundi and Asabamaka et al. in Nigeria, this link was not found [6] [16].

\section{Conclusion}

The frequency of fatty liver disease is high in patients with metabolic syndrome at the Brazzaville University Hospital. Male gender, lack of occupation and high level of education were the risk factors associated with the presence of steatosis. Thus, in patients with metabolic syndrome, fatty liver disease should be sought for early management.

\section{Conflicts of Interest}

The authors declare no conflicts of interest regarding the publication of this paper.

\section{References}

[1] Younossi, Z., Koenig, A., Abdelatif, D., et al. (2016) Global Epidemiology of Nonalcoholic Fatty Liver Disease-Meta-Analytic Assessment of Prevalence, Evidence and Outcomes. Hepatolgy, 64, 73-84. https://doi.org/10.1002/hep.28431

[2] Bedogni, G., Miglioli, L., Masutti, F., Tiribelli, C., Marchesini, G. and Bellentani, S. (2005) Prevalence of and Risk Factors for Nonalcoholic Fatty Liver Disease: The Dionysos Nutrition and Liver Study. Hepatology, 42, 44-52. https://doi.org/10.1002/hep.20734

[3] El-Serag, H.B., Lau, M., Eschbach, K., Davila, J. and Goodwin, J. (2007) Epidemiology of Hepatocellular Carcinoma in Hispanics in the United States. Archives of Internal Medicine, 167, 1983-1989. https://doi.org/10.1001/archinte.167.18.1983

[4] Clark, J.M. (2016) The Epidemiology of Nonalcoholic Fatty Liver in Adults. Journal of Clinical Gastro-Enterology, 40, S5-10.

[5] Ziol, M., Handra-Luca, A. and Kettaneh, A. (2005) Noninvasive Assessment of Liver Fibrosis by Measurement of Stiffness in Patients with Chronic Hepatitis C. Hepatology, 41, 48-54. https://doi.org/10.1002/hep.20506

[6] Ntagirabiri, R., Cikomola, J., Ndirahisha, E., et al. (2014) Stéatose hépatique lors du syndrome métabolique chez l'adulte noir africain: Cas du Burundi. Journal Africain d Hépato-Gastroentérologie, 8, 195-199. https://doi.org/10.1007/s12157-014-0553-9

[7] Crepaldi, G. and Maggi, S. (2006) Diabète et syndrome métabolique contexte historique du syndrome métabolique. In: Diabetes Voice, 51 (Edition spéciale), Fédération internationale du diabète, $8-10$. 
[8] Loomba, R., Serlin, C., Schwimmer, J., et al. (2009) Advances in Pediatric Nonalcoholic Fatty Liver Disease. Hepatology, 50, 1282-1293.

https://doi.org/10.1002/hep.23119

[9] Balkau, B., Vernay, M., Mhamdi, L., et al. (2003) The Incidence and Persistence of the NCEP (National Cholesterol Education Program) Metabolic Syndrome. The French D.E.S.I. R Study. Diabetes \& Metabolism, 39, 89-94.

[10] Yaméogo, T., Sombié, I., Kyélem, C.G., et al. (2014) Diagnostic et prevalence du syndrome métabolique chez les diabétiques suivis dans un context de ressources humaines limitées: Cas du Burkina-Faso. The Pan African Medical Journal, 19, 435-454. https://doi.org/10.11604/pamj.2014.19.364.3741

[11] Monabeka, H.G., Kimbally-kaky, G., Gombet, T., et al. (2012) Syndrome métabolique et prévalence des cardiopathies ischémiques au Centre Hospitalier et Universitaire de Brazzaville. Médecine des Maladies Métaboliques, 6, 75-79. https://doi.org/10.1016/S1957-2557(12)70365-6

[12] Mbaye, A., Babaka, K., Ngaide, A.A., et al. (2018) Prévalence des facteurs de risque cardio-vasculaire en milieu semi-rural au Sénégal. Annales de Cardiologie et d Angiologie, 67, 264-269. https://doi.org/10.1016/j.ancard.2018.04.005

[13] Hauhount-Attoungbré, M.L., Yayo, E.S., Konan, F., et al. (2013) Régime d’engraissement et syndrome métabolique en Côte d'Ivoire. Annales de Biologie Clinique (Paris), 71, 207-210. https://doi.org/10.1684/abc.2013.0808

[14] Douglas, J.G., Bakris, G.L., Epstein, M., et al. (2003) Management of High Blood Pressure in African-Amicans. Archives of Internal Medicine, 163, 525-541. https://doi.org/10.1001/archinte.163.5.525

[15] Shetty, P. (2013) Nutrition Transition and Its Health Outcomes. Indian Journal of Pediatrics, 80, 21-27. https://doi.org/10.1007/s12098-013-0971-5

[16] Asabamaka, O.C., Ogbera, A.O. and Balogun, B.O. (2011) Nonalcoholic Fatty Liver Disease and the Metabolic Syndrome in an Urban Hospital Serving African Community. Annals of Hepatology, 10, 119-124. https://doi.org/10.1016/S1665-2681(19)31559-5

[17] Rheeder, P., Morris-Paxton, A.A., Ewing, R., et al. (2017) The Noncommunicable Disease Outcomes of Primary Healthcare Screening in Two Rural Subdistricts of the Eastern Cape Province, South Africa. African Journal of Primary Health Care \& Family Medicine, 9, 234-245. https://doi.org/10.4102/phcfm.v9i1.1466

[18] Dixon, J.B., Bhathal, P.S. and O’Brien, P.E. (2001) Nonalcoholic Fatty Liver Disease: Predictors on Non-Alcoholic Steatohepatitis and Liver Fibrosis in the Several Obese. Gastroenterology \& Hepatology, 121, 91-100. https://doi.org/10.1053/gast.2001.25540

[19] Tarantini, G., Saldalamacchia, G., Conca, P., et al. (2007) Non-Alcoholic Fatty Liver Disease: Further Expression of the Metabolic Syndrome. Journal of Gastroenterology and Hepatology, 22, 293-303. https://doi.org/10.1111/j.1440-1746.2007.04824.x

[20] Solga, S.F., Clark, J.M., Alkhuraishi, A.R., et al. (2005) Race and Comorbid Factors Predict Nonalcoholic Fatty Liver Disease Histopathology in Severely Obese Patients. Surgery for Obesity and Related Diseases, 1, 6-11. https://doi.org/10.1016/j.soard.2004.12.006

[21] Bernsmeier, C. and Heim, M. (2011) Stéatose hépatique non alcoolique et stéatohépatite non alcoolique. Forum Suisse, 11, 53-57. https://doi.org/10.4414/fms.2011.07418

[22] Goedecke, J.H., Levit, N.S., Evans, J., et al. (2013) The Role of Adipose Tissue in Insulin Resistance in Women of African Ancestry. Journal of Obesity, 2013, Article ID: 952916. https://doi.org/10.1155/2013/952916 
[23] Somaya, S., Hommadi, A., Mouden, K., et al. (2012) Prévalence et caractéristiques générales des stéatopathies non alcooliques du foie chez les marocains diabétiques de type 2. Cahiers de Nutrition et de Diététique, 47, 50-56. https://doi.org/10.1016/j.cnd.2011.04.003

[24] Kaduka, U.L., Kombe, Y., Kenya, E., et al. (2012) Prevalence of Metabolic Syndrome among an Urban Population in Kenya. Diabetes Care, 35, 887-893. https://doi.org/10.2337/dc11-0537

[25] Dehout, F., Haumont, S., Gaham, N., et al. (2008) Metabolic Syndrome in Bantu Subjects with Type 2 Diabetes from Sub-Saharah Extraction: Prevalence, Gender Differences and HOMA Hyperbolic Product. Diabetes \& Metabolic Syndrome: Clinical Research \& Reviews, 2, 5-11. https://doi.org/10.1016/j.dsx.2007.11.008 